\title{
THE POTENTIAL DEVELOPMENT OF TOURISM ATTRACTION IN TOURISM DESTINATION OF IKAN SAKTI SUNGAI JANIAH, SUBDISTRICT BASO, DISTRICT AGAM, WEST SUMATRA
}

\author{
Hendri Azwar ${ }^{1}$ Dr. Himawan Brahmantyo, SE., MM ${ }^{2}$, \\ Ir. Henky Hermantoro, MURP / MPA ${ }^{3}$ \\ 1,2,3 Trisakti School of Tourism \\ hendriazwar5@gmail.com
}

\begin{abstract}
This study aims to analyze the potential development of a tourist attraction in Tourism Destinations of Ikan Sakti Sungai Janiah Kecamatan Baso Kabupaten Agam. This study used qualitative and SWOT analysis. The data source is Head of Tourism, Youth and Sports, the Chief Manager of Tourism Destinations, Community Leaders, and tourists. The techniques of data collection were through interviews, observation, and documentation. Data were analyzed qualitatively including reduction, data presentation, and conclusions. The results showed that the potential development of tourist attraction in this tourists destination is tracking, flying fox, fishing pond, bathhouse, camping area, playground, park, packaging art such as; Randai, dances, Debus, Talempong Pacik, Pupuik, Makan Bajamba, and Martial Arts Performances. Development strategies of a tourist attraction by optimizing the natural resources that already exist, giving training in tourism awareness to the community, building cooperation with local governments, managers and the public in the packaging of a tourist attraction, improve human resources by providing training and looking for investors in the development of tourist attraction, and increasing community involvement in the management of a tourist attraction.
\end{abstract}

Keywords: Potential, Development, Attractions, Destinations, SWOT

\section{INTRODUCTION}

Indonesia is one country where the tourism is a major sector to improve the national economy in overcoming poverty. It is proved in 2011 where the ranking of tourism foreign exchange reached the fifth rank of eleven exports of goods in Indonesia, which reached USD 8,544.39 million and increased by 2015 to USD $12,225.89$ million (kemenpar.go.id). Besides, it is also seen from the development of tourism industry in various regions in Indonesia.

World Tourism Organization describes the "Tourism comprises the activities of persons traveling to and staying in places outside their usual environment for not more than one consecutive year for leisure, Management, and other purposes 
The tourism development of a region needs the support and cooperation of relevant stakeholders such as governments, employers or Management as well as the surrounding community, particularly in exploring the potential of existing attraction. It aims to increase tourists visits to an area that can have a positive impact on revenue and economic areas.

According to Law No.10 of 2009 on tourism, Tourist Attractions is anything that has a uniqueness, beauty and value in the form of natural diversity, cultural and manmade outcome target or destination of tourists visit. Basically, tourist attraction is also a motivating factor tourist visited tourist destination, both a natural attraction (Natural Attraction), the attraction of culture (culture attraction) and the attractiveness of artificial (Man Made of Attraction).

Tourism Destinations of Ikan Sakti Sungai Janiah is one of the destinations in the district of Agam Baso will be developed by the government. This is seen in tourism development master plan of Agam 2016 which makes this destination as the Top Fourth Destination of Agam (DUPK4). This tourist destination is geographically located between $0^{\circ}$ $3^{\circ} \mathrm{S}, 100.28^{\circ} \mathrm{E}$, with an area of

\section{REVIEW OF RELATED LITERATURE Tourism}

Tourism is an activity, service, and products of the tourism industry to create new experiences for travelers. According to Law
19.19 KM2 is located at an altitude of 800-900 $\mathrm{m}$ above sea level.

The attractions are owned by these tourist destinations are the beautiful nature, flora, and fauna and the air is still fresh. Then, the cultural attraction has unique characteristics such as customs and life in society. Furthermore, the attraction made in the existing form of heritage buildings hereditary form of the Rumah Gadang (traditional house of Minangkabau tribe), which is still maintained up to this day. With the attraction of it, if it is well developed, could increase tourist visits to tourist destinations of Ikan Sakti Sungai Janiah.

In fact, nowadays, the level of tourists' visits to this tourist destination is still less stable. It can be seen from the low number of tourists' visits and the destination is still little known by tourists. Meanwhile, the tourist attraction strongly supports the survival and growth of regional tourism competitive basis and be able to have a competitive edge and more value than other tourism destinations. Therefore, this study was aimed to analyze the potential for tourists' destination development in Ikan Sakti Sungai Janiah Kecamatan Baso Kabupaten, West Sumatra.

No.10 of 2009 on tourism, "Tourism is a wide range of tourist activities and supported a variety of facilities and services provided by communities, Management, governments, and local governments" 
Tourism activities cannot be separated from tourism Management aimed at providing tourism services, supply, object seek, attractions, Management tourism facilities, and other related Management that field. In these activities occurred economic activity due to the demand on the part of tourists and offers from providers of tourism services provided by communities, Management, governments, and local governments.

\section{Tourism Destination}

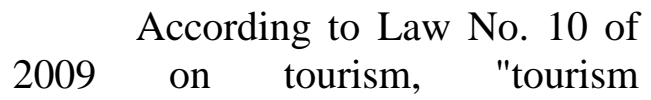
Destinations or a tourist destination is a geographical region located in one or more administrative regions in which there is a tourist attraction, public facilities, tourism facilities, accessibility, and community are interrelated and complementary realization of tourism.

In contrast to what was stated by Kelly and Narkervis (2001),"Effective coordination of a destinations tourism operations depends upon a clear understanding of the resources available, the extent to which tourism development has ready occurred, and the interrelationship among this development"

\section{Attractions}

Attractions is anything that has a uniqueness, beauty, and value in the form of natural diversity, cultural and man-made outcome target or destination tourist visits (Act No.10 of 2009). Suchaina (2014) presents three classification of tourist attraction, namely: "(a) the tourist attraction of nature (natural attractions), (b) cultural attractions, (c) a tourist attraction artificial / target man (man-made attractions)".

Elements of natural attraction is the sea, beaches, mountains, lakes, rivers, flora and fauna, landscapes and others; cultural attraction $\mathrm{s}$ is the tradition of customs, clothes of customs, ceremonies, cultural heritage, buildings and historic heritage, festivals and cultural performances, handicrafts, and others; and man-made attraction results are facilities for sports, entertainment games, recreation parks, national parks, shopping, and souvenirs etc .

\section{RESEARCH METHODOLOGY}

Research on Potential for Development Attractions in Ikan Sakti Sungai Janiah Kecamatan Baso Kabupaten, West Sumatra was using qualitative methods and SWOT analysis. According to Sugiyono (2011: 306) "Qualitative researchers as human instruments, serves to establish the focus of the problem, select informants as a source of data, collecting data, assessing data quality, data analysis, interpret the data and make conclusions on its findings".

This research was conducted by observation, interviews, and documentation. Sources of data in this study are the Head of Tourism, Youth, and Sports of Agam, Chairman of the Management of Ikan Sakti Sungai Janiah Tourism Destination, public recommended by the Chief Manager of Tourism Destinations of Ikan Sakti Sungai Janiah and tourist. 
Researchers tested the data credibility so that research results can be accounted for. According to Sugiyono (2011: 365), "test the credibility of the data or confidence in the results of a qualitative study among others the extension of observation, increased diligence in research, triangulation, discussions with colleagues, negative case analysis, and member check".

Techniques of data analysis used were qualitative and SWOT analysis. Techniques of Qualitative data analysis used the interactive model of Miles and Huberman (1984) in Sugiyono (2011: 334) "Activities in the data analysis that is data reductions, the data display, and conclusion drawing/ verification". Thus the qualitative data analysis techniques included three grooves; reduction, data presentation, and conclusions ". Formulating a Potential for Development in Ikan Sakti Sungai Janiah Tourism Destination, the researchers identified factors of strengths, weaknesses, opportunities, and threats using SWOT.

Rangkuti (2000: 18) argues SWOT analysis is: "Identification of a variety of factors systematically to formulate the corporate strategy. This analysis is based on the logic that maximises the strengths and opportunities but simultaneously can minimize your weaknesses and threats".

After conducting a SWOT analysis, researchers made a SWOT formulation which was prepared by using SWOT analysis results by combining several indicators contained in the strengths, weaknesses, opportunities, and threats. (Rangkuti, 2011).

\section{DESCRIPTION OF THE OBJECT OF RESEARCH}

Sungai Janiah is one Jorong (village) surrounded by the expanse of Bukit Barisan (the longest mountain in Sumatra) located in the district of Agam Baso. Sungai Janiah has its own uniqueness and beauty as beautiful nature and forests are still awake, uphold cultural mores with and its inhabitants.

Most of Sungai Janiah mainland is forest, rice fields, and plantations which are very beautiful and attractive. Sungai Janiah is geographically located between $0^{\circ}$ $3^{\circ} \mathrm{S}, 100.28^{\circ} \mathrm{E}$, with an area of \pm 4.2 $\mathrm{km} 2$ at an altitude of 800-900 meters above sea level.

Sungai Janiah tourism destinations had long been managed by the local community but at the end of 2016 a new cooperation with the Department of Tourism, Youth and Sports. Operational management is directly carried out by the public, while the government only as a supervisor and support the development of the tourism destinations.

\section{RESULTS}

\section{Natural Attractions}

Natural Attractions of Ikan Sakti Sungai Janiah Tourism Destination are some major natural attractions such as Bukik Batanjua where the hill has a uniqueness that is on the hilltop there is water in a clean stone, and you can drink directly. Based on the story can be a remedy for those who drink it 
Then the beautiful view from the top Bukik Batanjua also can be a natural attraction for tourists because from the top of the hill the tourists can see the views of the entire area of Sungai Janiah to Jam Gadang (Clock Tower), Bukittinggi although within $\pm 25 \mathrm{Km}$ from Ikan Sakti Sungai Janiah Tourism Destination.

For its development in the Bukik Batanjua, it potentially serves as a place for camping or tracking area as stated by the Chairman of Pokdarwis Sungai Janiah in the results of the interview:

"We have enough land and can create additional travel like the place for camping or tracking area. This program has not ever been planned because of their limited knowledge and development ways".

This development is still not conducted by the manager because there is constrained in planning the construction of stairs that have not been reaching one hundred percent completed as well as the manufacture of site planning camping. Then, the lack of management personnel for monitoring to the top of the Bukik Batanjua is also contributed. Consequently, there are widely found trash scattered on top of the hill.

While Magic Fish pond with the unique history where the origin of fish is from a human has become an attraction for tourists to come to this destinations. In addition, the much water flows from the pool can be developed becoming bathing or fishing spot for tourists later. Around the Magic fish pond, many apes which also can be its uniqueness, such as feeding the monkey. Moreover, because most of its population are farmers, there are many rice fields and crops that can be developed later as additional objects of tourism, as shown in Figure 1.

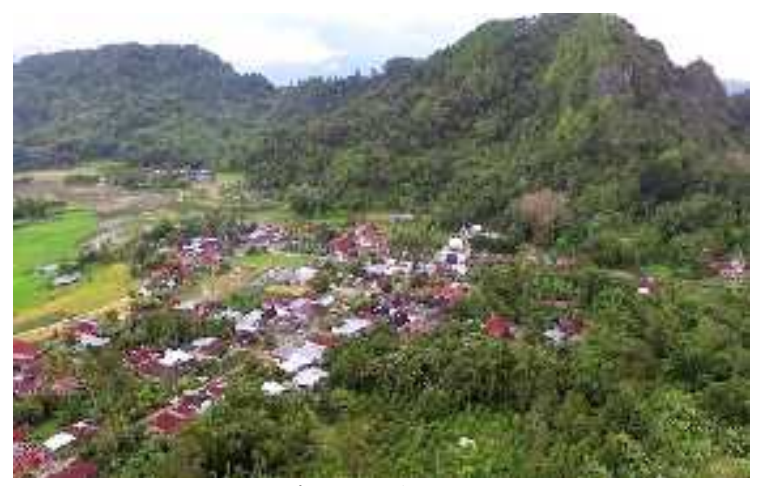

Figure 1.

In the development of tourism destinations of Ikan, Sakti Sungai Janiah is slow because of difficulties in land acquisition for tourism. Most of the land is owned by the native people or it is called as Tanah hulayat (the land which is owned by indigenous people or tribes land) so that in the planning of development, the government must be waiting for permission and agreement in advance of traditional leaders 
Thus the main natural attraction that exists (Bukit Batanjua, Magic Fish pond, Animal trademark and water sources) are likely to be developed with the manufacture of baths, fishing, and manufacturing of location for tracking and camping area on the hill. Next, to take advantage of big trees around the tourist sites can be developed into flying fox park later.This was stated by community leaders in Sungai Janiah.

"In this tourism
destination, we have a
beautiful nature and the
number of trees as well as
a source of water. One
example if we take
advantage of existing
trees, we can make as a
flying fox area that can
increase tourist visits as
well ".

The problem is the location has not been well managed as many of garbage left in the area because they lack specialized staff in cleaning locations. For the development and management, it needs cooperation between managers, local governments, and communities as well as investors in developing this potential. Then, cooperation with all parties promoting this site will increase tourist visits.

\section{Cultural Attraction}

There are a much cultural attraction in Sungai Janiah such as; the tradition of Baralek minang (marriage minang tribe where there is a procession with a tambourine) and its petatah petitih (adage proverb).Then, Randai performance (original art Drama of Minang) are randai simalanca originally from Sungai Janiah where it tells the life story of a simple young man who diligently worships. There are also art performances of Silek (Martial Arts community of Sungai Janiah) with three types of martial arts that are Silek Kumango (its movement combining soft and hard martial arts movements), Silek Tuo, (soft movements and lock). Silek taralak, (hard and sharp movements) by using their four philosophical movements Alief, Lam, Lam, Ha (Allah). In silat performance, we always remember God and pay attention to four nature and human nature (fire, water, the wind, and earth). This is in line with the Chairman of the Pokdarwis of Sungai Janiah that.

"If the cultural attraction is very much but not yet developed like the martial arts for example Silek Kumango, Silek Tuo, Silek taralak by using four movement whose philosophy Alief, Lam, Lam, Ha (Allah) in the Silat Performances, we always remember God and pay attention to four nature and human nature (Wind Fire Water and Soil). 


Then pasambahan
(proverb), randai,
talempoang and pupuik
(traditional musical
instrument minang) is
complete, then makan
bajamba (eating together
in the large plate)".

Furthermore, cultural attraction upon this tourism destination such as a musical instrument pupuik (a wind instrument of palm leaves), which is rarely found in the area of Minangkabau, playing talempoang Pacik (musical instrument talempong played during casual occasions such as while waiting for guests in a custom event or formal and tradition makan bajamba (eating together in sebuat large plates, one plate can be 4 to 6 where it symbolizes the togetherness of peopleMinang).

This is the attraction of the culture of the society of Sungai Janiah, but at this time the attraction is rarely seen, because of the lack of interest of young people to learn about the culture. Some youth choose to migrate so that very few generations in developing a culture in Sungai Janiah. This was stated by the head of the tourism department of youth and sports that:

"The weakness of the community itself is still a lack of interest and participation in moving and takes part in attraction development of this culture because most youths are also many who go abroad ".

The hope is if the cultural attraction is developed and packaged as a spectacle for tourists, it will give a positive impact on society of Sungai Janiah. It is not only as entertainment for tourists but also beneficial for the community to increase the awareness of their own culture and the local economy.

Making it real and pack the cultural attraction, the role of the community, management, and government are needed. It is in line with the motto of Kambali ka Nagai (revive the old culture). In addition, the strategies are introducing more people to the culture of children from an early age. This was stated by one of the community leaders in Sungai Janiah that:

"If we truly develop the attraction of this culture, it can be started from the other side, we go from elementary school. We train them while playing and later can be used mainly in developing this cultural attraction ".

While the government is expected to help develop this fascination with making local arts events that attract people to delve deeper into budayannya 


\section{Man-Made Attraction}

Man-Made attractions of the tourism destinations of Ikan Sakti Sungai Janiah are many like a traditional house of sapasukuan (a tribe) where each tribe had the house as a place of customary deliberation, cemetery sacred in Sungai Janiah (Grave of Inyiak Jirek) where people believe he is sacred man that has grave up to 4 meters long, and the magic fish story itself can be recorded. As stated by the Chairman of the Pokdarwis Sungai Janiah that:

"Every tribe in Sungai
Janiah have traditional
house sapasukuan (a
tribe) to which
musyawah or discussion
together. In addition,
there are also graves of
sacred named graves of
Inyiak Jirek with the
length up to 4 meters and
is considered sacred by
the community"

The other potential attraction that can be developed is the manufacture of a playing park as utilizing two potential natural and man-made can be made flying fox and a tree house. Next, the other potential is fishing and baths spot for tourists.

Nevertheless, the development of this potential is often constrained by niniak mamak (Traditional Leaders) to permit the development because it was feared did not fit the culture
Sungai Janiah. As stated by the Head of Tourism, Youth, and Sports that:

"The weakness of the community as possible in terms of possible awareness of tourism, in addition to any tourism development we must get prior permission from niniak mamak or tribal leaders, without his permission we cannot continue the development of tourism because the government simply as a supporter and supervisor, while the management is directly taking by the community".

The next potential is vacant land that can be used to manufacture the park around these destinations as well as the addition of the lodges will have a special uniqueness. It can be seen in Figure 2 below.

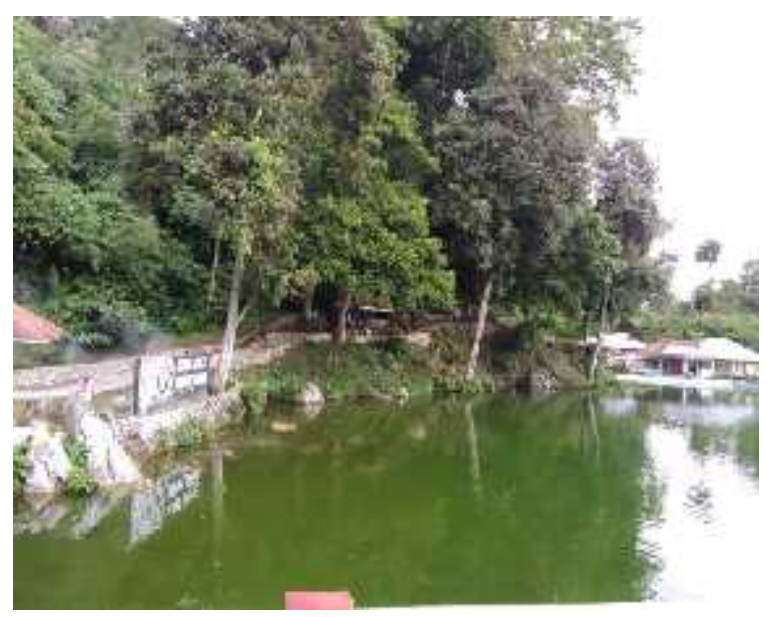

Figure 2. 
In addition to, improving the quality of human resources should also be considered, as it will play an active role against reciprocation of these destinations

\section{DISCUSSION}

Based on the results of
SWOT analysis (strengths,
weaknesses, opportunities, and
threats) the Potential Development of
Tourism Attractions in Tourism

Destinations of Ikan Sakti Sungai Janiah Kecamatan Baso Kabupaten Agam, West Sumatra can be explained as follows:

\section{1) Natural Attraction}

SWOT Analysis of natural attraction of Tourism Destination in Ikan Sakti Sungai Janiah Kecamatan Baso Kabupaten Agam, West Sumatra can be seen in Table 1 below:

Table 1. SWOT Analysis of Natural Attraction the Tourism Destinations of Ikan Sakti Sungai Janiah

\begin{tabular}{|c|c|}
\hline Strength $(\mathrm{S})$ & Weakness (W) \\
\hline $\begin{array}{l}\text { 1) Formation Pokdarwis (Tourism } \\
\text { Awareness Group) by the } \\
\text { Government which is staffed by } \\
\text { people around Tourism Destinations } \\
\text { of Ikan Sakti Sungai Janiah. } \\
\text { 2) A beautiful natural attraction and the } \\
\text { air is still maintained fresh and free } \\
\text { from air pollution. } \\
\text { 3) The presence of several other } \\
\text { interesting places that have not been } \\
\text { developed as a tourist attraction. } \\
\text { 4) Location or strategic place and easy } \\
\text { to reach } \pm 2.5 \text { Km of causeway } \\
\text { Sumatra. While the distance to } \\
\text { Bukittinggi } \pm 23 \text { Km which is one of } \\
\text { the Featured destinations in West } \\
\text { Sumatra. } \\
\text { 5) Availability of water sources }\end{array}$ & $\begin{array}{l}\text { 1) People lack knowledge and science } \\
\text { in the utilization of natural } \\
\text { resources. } \\
\text { 2) Not all people who understand } \\
\text { tourism awareness } \\
\text { 3) Difficulties in assessing permission } \\
\text { from niniak mamak (Traditional } \\
\text { Leaders) in land use and the entry of } \\
\text { outside investors for tourism } \\
\text { development. } \\
\text { 4) The government only coaches, } \\
\text { management is fully carried out by } \\
\text { the public, so that limitation in } \\
\text { developing tourism professionals }\end{array}$ \\
\hline Opportunities $(\mathrm{O})$ & Threats (T) \\
\hline $\begin{array}{l}\text { 1) The number of tourists visiting } \\
\text { Agam is big enough. } \\
\text { 2) Cooperation, central government } \\
\text { agencies and local governments and } \\
\text { academia in the development of } \\
\text { tourism destinations. }\end{array}$ & $\begin{array}{l}\text { 1) The development of tourism } \\
\text { destinations that enhance } \\
\text { competition } \\
\text { the development of other tourist } \\
\text { destinations are located in the } \\
\text { tourism destination of Ikan Sakti }\end{array}$ \\
\hline
\end{tabular}


3) Determination by local government tourism destinations Ikan Sakti Sungai Janiah into a major destination to be developed.

4) They still lack the natural attractions that exist around tourism destinations.
Sungai janiah can increase competition

3) The natural damage was done by tourists if the number of tourists is not noticed.

4) The threat of natural disasters, because the destination is located on a hilly terrain.

Based on the results of SWOT analysis of the natural attraction above, it can be arranged strategy development as follows (Table 2):

Table 2. Strategy Development of Natural Attraction in Tourism Destinations of Ikan Sakti Sungai Janiah

\begin{tabular}{|c|c|}
\hline SO Strategies (Strength-Opportunity) & $\begin{array}{l}\text { WO Strategies (Weaknesses- } \\
\text { Opportunities) }\end{array}$ \\
\hline $\begin{array}{l}\text { 1) Empower HR (Pokdarwis) to } \\
\text { cooperate with related agencies } \\
\text { such as government and private } \\
\text { 2) Utilizing natural attraction by } \\
\text { adding new objects which can be } \\
\text { visited by tourists. } \\
\text { 3) Developing natural attractions such } \\
\text { as the manufacture of a camping } \\
\text { area, tracking, and utilization of } \\
\text { water resources by making a } \\
\text { bathhouse, fishing and rafting }\end{array}$ & $\begin{array}{l}\text { 1) Maximizing the attraction of } \\
\text { existing natural } \\
\text { 2) Provide training to the community } \\
\text { of tourism awareness } \\
\text { 3) Better approach to niniak mamak } \\
\text { for land use will be used as a natural } \\
\text { attraction development } \\
\text { 4) Government training and full } \\
\text { support to the managers and the } \\
\text { community for the development of } \\
\text { this tourism destination. }\end{array}$ \\
\hline & esses-Threats) \\
\hline $\begin{array}{l}\text { 1) Perform maintenance and care of the } \\
\text { natural environment by renewing } \\
\text { natural resources and limit the } \\
\text { number of tourists visiting, so as to } \\
\text { preserve the natural } \\
\text { 2) the Management community should } \\
\text { be helped by heavily promoting. } \\
\text { 3) Utilizing a water source well to pay } \\
\text { attention to the environmental } \\
\text { damage and the potential for natural } \\
\text { disasters. }\end{array}$ & $\begin{array}{l}\text { 1) Implanting the managers and the } \\
\text { public to provide excellent service } \\
\text { to travelers with the training of } \\
\text { government and academia. } \\
\text { 2) Local government, Management, } \\
\text { community and niniak mamak to } \\
\text { make a rule to tourists (in the form } \\
\text { of what is permissible and what is } \\
\text { not) } \\
\text { 3) Management and the community } \\
\text { should do a comparative study to } \\
\text { other tourism destinations. }\end{array}$ \\
\hline
\end{tabular}


Empower the entire SDM (Pokdarwis) in accordance with the portions and the assignment of responsibilities of each. The Management destination must actively cooperate with the government, such as asking for training, guidance, and assistance in order to develop a natural attraction to the maximum. Managers can conduct cooperation with the private sector that could eventually become investors in the construction of natural attraction in particular. In addition to the manager, the active role of the community is needed to support the development of tourism destination attractiveness, because society is a major tourism player.

Utilization of natural attraction, it can improve the local economy directly. This is in line with that proposed by Hermantoro, (2015: 2), "Tourism has also provided evidence that natural resources can be processed into a great economic power without damaging the environment." This strategy is done by the management and the community with local government and private ready for a human.

Developing natural attractions such as the manufacture of a camping area, tracking, and utilization of water resources by making a bathhouse, fishing and rafting are aimed to increase the capacity rating so it does not accumulate in one place. This can be done by the management with the support of the public and mamak niniak in the particular and direction of the government.

Provide insight to the community, especially on tourism awareness and training and full support to the managers and the community for the development of tourism destinations in Sungai Janiah. This is achieved by governments as well as the support of academics that aims to increase the sense of belonging and the ability of communities to develop tourism. Perform maintenance and care of the natural environment by renewing natural resources such as the planting of trees. Limiting the number of tourists visiting several objects which aim to maintain the balance and preservation of nature so there is no damage caused by the number of tourist visits.

Promotion of tourism destinations by the management assisted local communities to do with the distribution of brochures, social media, and promotions directly to potential tourists.

Utilizing the existing water resources properly can be done by considering the environmental damage and the potential for natural disasters. There are a lot of potentials that can be developed by utilizing the existing water sources such as adding water parks. But its use must be considered so as to avoid contamination of the environment. This analysis is done by the management with the help of local government and academia.

Creating a rule for the tourists when visiting tourist destinations such as courtesy visit, dress, behave and others who should be in accordance with the customs of the people (in the form of what is permissible and what is not). It was designed by the organizer and local governments to engage with traditional leaders as imposing a rule 
in the area. Management and the community should do a comparative study to other tourism destinations are already running and well developed. It aims to open up ideas and increase knowledge and insight in the development of society and the management of natural tourism destination in particular. The strategy can be carried out and supervised by the local government.

\section{2) Cultural Attraction}

Based on the analysis of cultural attraction in Ikan Sakti Sungai Janiah Kecamatan Baso Kabupaten Agam, West Sumatra can be seen in Table 3 below:

Table 3: SWOT Analysis of Culture of Attraction the Tourism Destinations of Ikan Sakti Sungai Janiah

\begin{tabular}{|c|c|}
\hline th $(S)$ & Weakness (W) \\
\hline $\begin{array}{l}\text { 1) Society upholds the philosophy of } \\
\text { Minangkabau " Adaik basandi } \\
\text { syarak, syarak basandi kitabullah." } \\
\text { The strong community mores. } \\
\text { 2) A diverse array of the indigenous } \\
\text { culture of the community. } \\
\text { 3) Their respective tribes (Leaders of } \\
\text { Indigenous) understand the customs, } \\
\text { culture, and arts of Sungai Janiah } \\
\text { 4) their custom events are conducted } \\
\text { each month }\end{array}$ & $\begin{array}{l}\text { 1) Lack of interest and participation } \\
\text { (Youth) in the development of } \\
\text { culture } \\
\text { 2) Most people (Youth) went far and } \\
\text { wide and the Kampong just parents } \\
\text { A } \\
\text { 3) Lack of availability of facilities and } \\
\text { equipment, especially equipment } \\
\text { indigenous traditional music which } \\
\text { is endangered. } \\
\text { 4) The number of rules and } \\
\text { "abstinence" (prohibition) is } \\
\text { assumed by the public. } \\
\text { 5) Management and government have } \\
\text { no special funds for the } \\
\text { development of the cultural } \\
\text { attraction. } \\
\text { 6) Local governments merely as a } \\
\text { supporter and supervisor the } \\
\text { development of this cultural } \\
\text { attraction. }\end{array}$ \\
\hline Opportunities (O) & Himeats (1) \\
\hline $\begin{array}{l}\text { 1) The government plans to implement } \\
\text { a cultural event in this tourism } \\
\text { destination. } \\
\text { 2) The absence destinations develop } \\
\text { cultural attraction around sub district } \\
\text { Baso. } \\
\text { (1) The Government fully supports the } \\
\text { development potential of culture as a }\end{array}$ & $\begin{array}{l}\text { 1) Influence modernization and } \\
\text { technology that may affect the } \\
\text { cultural } \\
\text { 2) presence of foreign cultural } \\
\text { influences brought by tourists } \\
\text { 3) Competition with tourist } \\
\text { destinations in West Sumatra who } \\
\text { are already expanding cultural }\end{array}$ \\
\hline
\end{tabular}


tourist attraction.

attraction.

(2) Their investors who would like to help pack and become EO in the packaging of the cultural attraction.

(3) Their target of indigenous culture academics against Sungai Janiah, so it can serve as guidelines in its development.

Based on the results of SWOT analysis of cultural attraction of the above, it can be arranged as a development strategy follows (Table 4):

Table 4. Strategy Development culture attraction in the Tourism Destinations of Ikan Sakti Sungai Janiah

\begin{tabular}{c|c}
\hline SO Strategies (Strength-Opportunity) & $\begin{array}{c}\text { WO Strategies (Weaknesses- } \\
\text { Opportunities) }\end{array}$ \\
\hline
\end{tabular}

1) Management in cooperation with 1) Train and inculcate the culture of society, academia and government in culture and procurement packaging events to introduce the culture of the area rivers janiah so as to attract tourists the youth from the school so that it can maintain the original culture Sungai Janiah.

2) To coordinate with indigenous leaders about the native culture of the river janiah and map out where the culture (arts, martial arts, proverb etc.) that could be developed as a cultural attraction $s$ in tourism destinations fish sacred river janiah

3) find funds to improve and complement the equipment needed in the development of the attraction the culture, with the support and guidance academia and government

\section{ST Strategies (Strength-Threats)}

1) Community leaders (traditional leaders) and managers collaborate to create a rule for a tourism destination which is then published to tourists.

2) Following the development of technologies to optimize or use it as a promotional tool while maintaining the native culture.

\section{WT Strategies (Weaknesses-Threats)}

1) Empowering youth area as the driving force local tourism by providing training and understanding of the tourism

2) Identify abstinence (prohibition) who assumed the community and make it as a unique area

3) Improving facilities to support the implementation of a cultural event as an attraction for tourists 
Based on Table 4 above it can be seen that the strategy to develop a cultural attraction in Tourism Destinations of Ikan Sakti Sungai Janiah Kecamatan Baso Kabupaten Agam, West Sumatra can be done in several ways.

Management cooperates with society, academia, and government in the packaging of such cultural customs and uniqueness of a society which is then used as an attraction. Then the manufacture and supply of events culture aimed at introducing local culture Sungai Janiah so as to attract tourists. The government can create a calendar of cultural events that can be done at Tourism Destinations of Ikan Sakti Sungai Janiah. In this case, the community is as the executor of the event.

Cultural attractions that can be developed are randai, martial arts, traditional musical instruments and traditions of indigenous communities like makan bajamba. This packaging is done by managers with the support of the community as the main actor. Then, the private sector helps as a tourism destination to travelers carrying fish janiah sacred river, so that can improve the local economy.

Community leaders (traditional leaders) and managers collaborate to create a rule in tourism destinations which are then posted to the tourists. This can be done by displaying the rules been near the gate to enter the tourism destination and publications via the internet so that tourists can understand the area prior to travel and can maintain the cultural authenticity of local communities.

Following the development of technologies to optimize or use it as a promotional tool while maintaining the native culture. This can be done by empowering all the technology used by the public, such as communication technology (Android), the public can help the promotion of indigenous culture through the Internet so that the culture better known again.

At least the young man who understands the culture or customs to do the training and instill the concept of culture to the youth from the school so that it can maintain the original culture Sungai Janiah. If it is not done then the native culture in the sacred river tourism destination janiah fish can be lost.

Managers can coordinate with indigenous leaders about native culture and mapped Sungai Janiah where the culture (arts, martial arts, proverb etc.) that could be developed as an attraction in the cultural tourism destination of Ikan Sakti Sungai Janiah. This is done because not all of the existing culture can be used as a supporting passage of tourism in Ikan Sakti Sungai Janiah Tourism Destination.

Managers must be active in finding funds and assistance to reorganize and equip the equipment needed in the development of cultural attraction. This can be done through cooperation with investors with the support and direction of academia and the government 
Empowering youth as a driver of tourism in the region is by providing training and understanding of the local culture, especially tourism. This can be done by applying the "kambali kanagari" (back to culture). It can do as turn on and train young people to learn the culture. This strategy can be carried out by the management with the help of traditional leaders. In addition, improving facilities can support the implementation of a cultural event as an attraction for tourists such as the manufacture of the stage arts, and complete the necessary equipment. This can be done by the management with the help of the local government.

\section{1) Man Made Attraction}

Based on an analysis SWOT man made attraction in Tourism Destinations of Ikan Sakti Sungai Janiah Kecamatan Baso Kabupaten Agam, West Sumatra can be seen in Table 5 below:

Table 5. SWOT Analysis of Attraction Man Made the Tourism Destinations of Ikan Sakti Sungai Janiah

\begin{tabular}{|c|c|}
\hline Stren & Weakness (W) \\
\hline $\begin{array}{l}\text { 1) The empty land area for the } \\
\text { manufacture of man-made attraction } \\
\text { tourism destination fish sacred river } \\
\text { janiah } \\
\text { 2) Lack of attraction of artificial around } \\
\text { tourist destinations fish sacred river } \\
\text { janiah }\end{array}$ & $\begin{array}{l}\text { 1) There is still a lack of knowledge in } \\
\text { the communities in developing this } \\
\text { potential. } \\
\text { 2) The trouble permission from } \\
\text { traditional authorities for land use in } \\
\text { the development of artificial } \\
\text { attraction. } \\
\text { 3) There is still a lack of creative ideas } \\
\text { from managers and communities to } \\
\text { develop or create attraction artificial } \\
\text { in tourism destinations have }\end{array}$ \\
\hline Opportuniti & Threats (T) \\
\hline $\begin{array}{l}\text { 1) There is support for local } \\
\text { governments to the development of } \\
\text { the attractiveness of artificial in } \\
\text { tourism destinations fish sacred river } \\
\text { janiah } \\
\text { 2) the existence of investors to help } \\
\text { develop the attractiveness of } \\
\text { artificial in this destination. } \\
\text { 3) Lack the attraction of artificial } \\
\text { around tourist destinations Ikan } \\
\text { Sakti Sungai Janiah } \\
\text { 4) Government will provide financial } \\
\text { assistance based on a proposal made }\end{array}$ & $\begin{array}{l}\text { 1) Competition with other tourism } \\
\text { destinations had first developed an } \\
\text { artificial attraction in West Sumatra. } \\
\text { 2) The influence of rating, the } \\
\text { incompatibility of tourist behavior } \\
\text { with the local culture. } \\
\text { 3) Lack of funds to undertake the } \\
\text { construction of artificial attraction. } \\
\text { 4) The regulation which states that } \\
\text { local governments cannot build } \\
\text { physically in a destination that is not } \\
\text { managed by the Government }\end{array}$ \\
\hline
\end{tabular}


by the management of tourism destinations

5) the existence of cooperation with academia in the development of this fascination

Having in mind the strengths, weaknesses, opportunities, and threats of man-made attraction in Tourism Destinations of Ikan Sakti
Sungai Janiah in District Baso Agam West Sumatra, the strategy of development can be seen in Table 6 below

\section{Table 6.Development Strategy Man Made Attraction in Ikan Sakti Sungai Janiah Tourism Destination}

\section{SO Strategies (Strength-Opportunity)}

1) Utilize and optimize the function of land surrounding tourist destinations to develop a man made attraction

2) Increase cooperation with local governments, academia and the private sector in developing a man made attraction to investors and increased opportunities for destination development

\section{ST Strategy (Strengths-Threats)}

1) creating a man made attraction with land use around the destination in accordance with the social life of the community to create characteristics own distinctive tourism destination

2) Conducting a comparative study of tourism destination that has been developed in the management of an artificial attraction and makes it as a tourism partner

\section{WO Strategies (Weaknesses-} Opportunities)

1) academics Local Government supported training and guidance to the public related to the development of man-made attraction so that more creative people participated to create the attraction made in

2) Management of tourism destinations should involve their respective traditional leaders in a caretaker manager of tourism destination Strategy WT (Weakness-Threat)

1) Provide training to the public related to the development of artificial attraction and conduct a comparative study into the tourism destination which is superior in a homemade attraction.

2) Making traditional leaders as rule makers or advisors in the management of tourism destinations
Based on Table 6 above can be explained that the strategy to develop a man made attraction in Tourism Destinations of Ikan Sakti Sungai Janiah in District Baso Agam West Sumatra can be done in several ways, namely by utilizing and optimizing the function of land around the existing tourism destinations to develop a man made attraction such as the manufacture flying fox, lodges, tree house, playground and more 
The use of the land can be carried out with the support of the community and community leaders around. It is because most of the land around the destination is inheritance. With the addition and development of artificial attraction, it can increase tourist visits.

Managers improve cooperation with local governments, academia and the private sector in developing a man made attraction to investors and increased opportunities for destination development. LG is a driving force in the development of the artificial attractiveness as help provide planning and training to managers later. Academics have an important role in increasing related human resources, such as managers and the public as actors will travel. As for the increase in the construction of an artificial attraction, it is required of investors who are capable of carrying out the construction. This cooperation with stakeholders can increase tourist arrivals and boost the local economy.

Creating artificial fascination with surrounding land use destination is in accordance with the social life of the community to create a unique tourism destination of Ikan Sakti Sungai Janiah. This is done by managers with the support of the local government to build artificial fascination with the feel of a typical Minang. Then make the attraction of the artificial can be enjoyed by all types of travelers.

Doing a comparative study to the tourism destination that has been developed in the management of artificial attractiveness and makes it as tourism partners. Management and society are working together to create an artificial attraction as well as providing excellent service management. This can be done by looking at the destinations that have been developed as a reference and guide to the desires of tourists.

Local Government supported academics provide training and coaching to the public related to the development of man-made attraction so that more creative people participated create an artificial attraction. This strategy can be performed more detail by governments, especially in the physical improvement of the attraction made in academics while helping to provide training in the management tbsp artificial attraction.

Management in creating an artificial attraction involves each traditional leader as the team manager of the entry in the organization of tourism destination. It aims to accelerate the construction and development of artificial attraction, because in that region in any development undertaken must be approved by traditional leaders first. Besides, traditional leaders are included in the creating rules for tour players and tourists.

\section{CONCLUSIONS AND RECOMMENDATIONS Conclusions}

The potential development of tourist attraction in Tourism Destinations of Ikan Sakti Sungai Janiah can be seen from the aspect of the strengths, weaknesses, opportunities, and threats. 
a. Strength:

1) There is an already organization or groups in managing tourist attraction in the tourism destination that is Pokdarwis (Tourism Awareness Group), which was confirmed by the tourism department in early 2017. The

2) Natural attraction of pariwista Destinations of Ikan Sakti Sungai Janiah was still awake and has the fresh air.

3) Location or strategic place and easy to reach $\pm 2.5 \mathrm{Km}$ of causeway Sumatra. While the distance to Bukittinggi \pm 23 $\mathrm{Km}$.

4) A number of vacant lands that could be used for the development of a tourist attraction.

5) Uphold a customary philosophy basandi adat basandi syarak, syarak basandi kitabullah. In a habitual way of life, social and religious.

6) The existence of a characteristic of a tourism attraction in Ikan Sakti Sungai Janiah Tourism Destinations as natural, traditional houses, cultural and social

b. Weakness

1) Trouble permit investors who will invest in the development of a tourist attraction as decision makers in the region are niniak mamak or indigenous leaders.

2) Knowledge and understanding of community tourism awareness are still lacking.
3) Management of tourist attraction is only allowed people around so the lack of professional personnel.

4) Lack of youth participation and interest in the management and development of tourist attraction.

5) The government does not have full authority for the development of tourist attraction in these destinations and the government only as advisors and supporter

c. Opportunities

1) Presence of cooperation of central government agencies and local governments in the promotion and development Travel Attractions in Ikan Sakti Sungai Janiah Tourism Destinations.

2) Their cooperation and guidance conducted by academics in floating tourist attraction.

3) Lack of developed tourist attraction around the District Baso Agam.

4) A number of tourists visiting Agam are increasing every year.

5) LGs establish tourism destination of Ikan Sakti Sungai Janiah is one of the main destinations that will be developed in Agam District.

6) The presence of outside investors who will develop a tourist attraction in Tourism Destinations of Ikan Sakti Sungai Janiah 
d. Threats

1) Modernization Influence, behavior and culture brought the tourists can affect local cultural

2) Development of tourist attraction in the tourism destination other near Tourism Destinations of Ikan Sakti Sungai Janiah

3) Number of tourist arrivals who are uncontrolled can damage the environment

4) The threat of natural disasters

\section{Suggestion}

1. Office of Tourism Youth and Sports of Agam

Doing coaching and training to managers and local communities periodically such as understanding tourism awareness and sapta pesona as well as how the development of a tourist attraction. Then, local government should be more aggressively conduct a campaign to highlight a tourist attraction by organizing events which will be published in the media social, so that it can increase tourist traffic which can positively impact the local economy.

2. Management

Tourism Destinations

They are expected to see the potential tourist attraction to realize the development strategy of natural attraction and artificial attraction in Tourism destination of Ikan Sakti Sungai Janiah. They should play an active role in cooperation with various parties such as the government was directing and supporting the advancement of tourism, academics doing research for a tourism destination so that the received input and advice in developing, finding investors who can support the physical development.

3. The next writer

It is expected to conduct further research in the development of a tourist attraction in Tourism Destinations of Ikan Sakti Sungai Janiah in the form of natural attraction, artificial attraction, and man-made attraction so that it becomes the input and materials for the advancement of the tourism destinations.

\section{REFERENCES}

Hermantoro, Henky, 2015. Kepariwisataan Destinasi Pariwisata Produk Wisata. Depok: Aditri.

Kelly, Ian dan Tony Nankervis, 2001. Visitor Destinations. Sydney: Calaloguins

Rangkuti, Fredy. 2000. Analisis SWOT Teknik Membedah Kasus Bisnis. Jakarta: Gramedia Pustaka Utama 
2011. SWOT

Balanced Scorecard. Jakarta:

PT. Gramedia Pustaka Utama.

Rencana Induk Pembangunan Kepariwisataan Kabupaten Agam, 2016

Suchaina. 2014. Pengaruh Kualitas Fasilitas Sarana Dan Prasarana Terhadap Peningkatan Jumlah
Pengunjung Wisata Danau Ranu Grati. Jurnal Psikologi. Pasuruan.

2011. Metode Penelitian Kombinasi (Mixed Methods). Yogyakarta: Alfabeta.

Undang-undang Republik Indonesia No.10 tahun 2009 tentang Kepariwisataan. 